\title{
Geomorphologic and Lithologic Evidence for an expanded Mountain Ice Sheet on Mount Kenya during the Early Quaternary
}

\author{
William C. Mahaney *)
}

Early Pleistocene, pre-Brunhes period, glacial landforms, glacial sequence, paleoclimatic studies, geomorphologic studies

Africa - Mount Kenya

\begin{abstract}
The analysis and interpretation of pre-Brunhes $(>.73-.79 \mathrm{my})$ glacial landforms in the Nithi River Basin, on the eastern flank of Mount Kenya, provide evidence for the dynamics of early Quaternary ice. The glacial sequence is composed of multiple sequences of ground and end moraines with associated crevasse fillings, outwash and aeolian deposits, and thin deposits of waterlain tills. These landform morphosequences represent two distinct glaciations with the older (Gorges Glaciation) being more extensive than the younger (Lake Ellis Glaciation). The Gorges Glaciation began with deposition of waterlain till on weathered tuff followed by deposition of end, hummocky-end and ground moraines, crevasse fillings, and aeolian deposits. The Lake Ellis Glaciation began with deposition of end and ground moraines and outwash deposits on weathered tuff, followed by emplacement of aeolian sediments.
\end{abstract}

Paleoclimatic and glacial geomorphologic inferences can be drawn after studying the sediments, degree of weathering, and landform relationship. Waterlain till near the margin of the Gorges Glaciation appears to be derived from subglacial deposition of sediment in an aquatic environment. The overlying till appears to be basal till. Hummocky end moraines represent ice stagnation during a later stage of the Gorges Glaciation that led to emplacement of meltout debris and some lodgement till. Crevasse fillings near these hummocky-end moraines indicate static ice margins that eventually wasted away at the end of the Gorges Glaciation. A somewhat similar morphosequence, emplaced during the Lake Ellis Glaciation, began with the construction of prominent end and ground moraines, followed by deposition of outwash bodies. No crevasse fillings or hummocky moraines were observed associated with this younger set of glacial landforms.

*) Address of the author: Prof. W. C. Mahaney, Dep. of Geography, Atkinson, College, York University, 4700 Kelle Street, North York, Ontario, Canada M3J 1 P3.

\section{[Geomorphologische und lithologische Belege für eine ausgedehnte altquartäre Vereisung des Mont Kenya]}

Kurzfassung: Die Analyse und Interpretation glazialer Formen der Prä-Brunhes Periode ( $>0,73-0,79$ my) im Einzugsgebiet des Flusses Nithi an der Ostflanke des Mount Kenya läßt typische Merkmale der Dynamik altquartärer Vereisungen erkennen. Die glaziale Serie setzt sich aus mehreren Folgen von Grund- und Endmoränen, subglazialen Füllungen von Gletscherspalten, Schmelzwasserablagerungen und äolischen Sedimenten zusammen. Hinzu kommen geringmächtige Lagen subaquatisch abgelagerten Moränenmaterials.

Die Formensequenz repräsentiert zwei ausgeprägte Vereisungsphasen, von denen die ältere (Gorges Vereisung) eine größere Ausdehung erreicht als die jüngere (Lake Ellis Vereisung). Die Gorges Vereisung begann mit der Ablagerung von Moränenmaterial unter Wasser über verwitterten Tuffen gefolgt von kuppiger Endmoräne, subglazialen Spaltenfüllungen und äolischen Ablagerungen. Zu Beginn der Lake Ellis Vereisung wurde End- und Grundmoränenmaterial sowie Schmelzwasserablagerungen über verwitterten Tuffen sedimentiert. Danach wurden äolische Sedimente gebildet.

Die paläoklimatischen und glazialmorphologischen Wechselwirkungen können durch die Untersuchung der Sedimente und deren Verwitterungsgrad sowie der speziellen Formen ermittelt werden. Nahe dem Eisrand der Gorges Vereisung wurde Material in einem aquatischen, subglazialen Milieu abgelagert. Die überdeckende Moräne kann als basaler Geschiebelehm angesehen werden. Kuppige Endmoränen repräsentieren eine spätere Phase der Stagnation des Eises während dieser Periode, an deren Ende es schließlich zur Ablagerung von Abtaumoränen und geringmächtigem Geschiebelehm kam. Subglaziale Spaltenfüllungen in der Nachbarschaft der kuppigen Endmoräne geben Hinweise auf einen statischen Eisrand am Ende der Gorges Vereisung. 
Eine in mancherlei Hinsicht ähnliche Formenvergesellschaftung der Lake Ellis Vereisung setzte mit der Entstehung von markanten End- und Grundmoränenkörpern ein. Ihnen folgte die Überdeckung durch Schmelzwasserablagerungen. Aus subglazialen Spaltenfüllungen hervorgegangene Formen und kuppige Moränen konnten für die jüngere Vereisung nicht beobachtet werden.

\section{Introduction}

Mount Kenya (Fig. 1) is the second highest (5199 m) mountain in East and Central Africa. Only Kilimanjaro is higher and both were glaciated extensively during the Quaternary. Because Mount Kenya is older (age of the volcanic plug rock $=2.6 \mathrm{~m}$. y.; EVERDEN and CURTIS, 1965) than Kilimanjaro one might expect to find the oldest moraines around the margin of glaciation in the lower valleys. Early investigations of the glacial geology of Mount Kenya were carried out by GREGORY (1894, 1900) and NiLSSON (1931, 1935). Both reported "older" till at $2990 \mathrm{~m}$ in Teleki Valley on the western side of the mountain (for a review see: VORTISCH, MAHANEY and FECHER, 1987). NILSSON also postulated the presence of "older moraine" below the Gates at $\sim 3100 \mathrm{~m}$ (Fig. 1) on the eastern flank of the mountain. Later BAKER (1967) noted the presence of "older" drift in Gorges Valley at $~ 3300 \mathrm{~m}$.
MAHANEY (1979, 1982) subdivided this "older" till into two tills (Teleki and pre-Teleki till, see BARENDREGT and MAHANEY, 1988) both of which predate the last glaciation. Both tills have normal magnetic polarity and are presumably younger than $730,000 \mathrm{yr}$. (MAHANEY, BARENDREgT \& VORTISCH, 1989). PreTeleki Till was renamed $\mathrm{N}$ a r o $\mathrm{M}$ or u Till by MAHANEY, BARENDREGT \& VORTISCH (1989).

Between $2850 \mathrm{~m}$ and $3150 \mathrm{~m}$ in Gorges Valley, on the eastern flank Mount Kenya, a sequence of moraines (Fig. 1) and related sluiceways provide evidence for earlier glaciations as old as the Olduvai subchron (1.67-1.87 my) (MAHANEY, BARENDREGT \& VORTISCH, 1989). In this paper the geomorphological evidence for these older glaciations-Gorges (older) and Lake Ellis (younger) - is described and discussed along with paleoclimatic/environmental interpretations.

\section{Methods}

Landforms were mapped from, 1:50000 stereo pairs (RAF photography 1947, 1963) and LANDSAT imagery (Fig. 1). Paleosol decriptions are based on criteria established by the SOIL SURVEY STAFF $(1951,1975)$ and BIRKELAND (1984). Weathering rinds were meas-

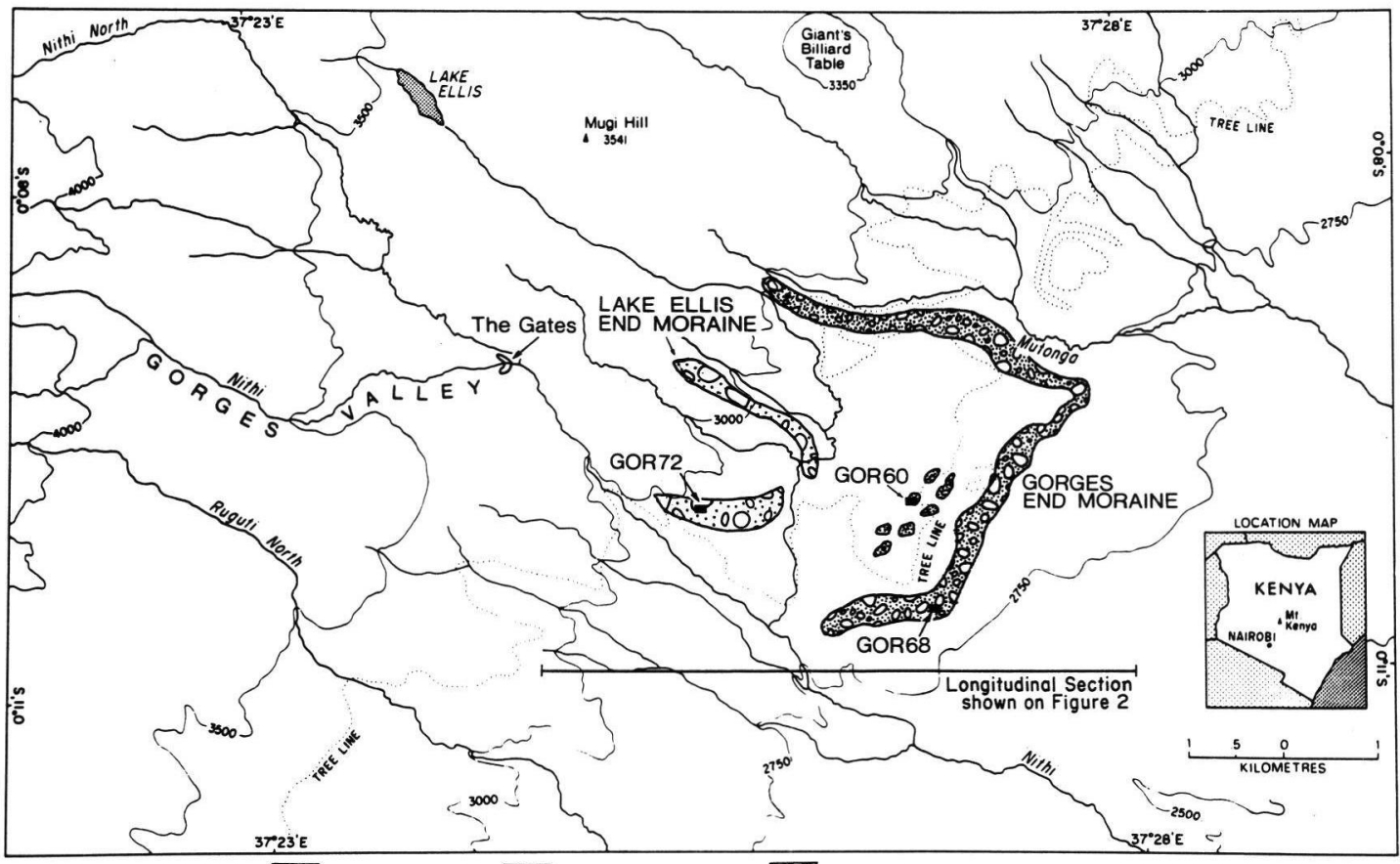

Lake Ellis till Gorges till (late)

Fig. 1: Map of moraine limits, drainages and topographic features referred to in the text. 


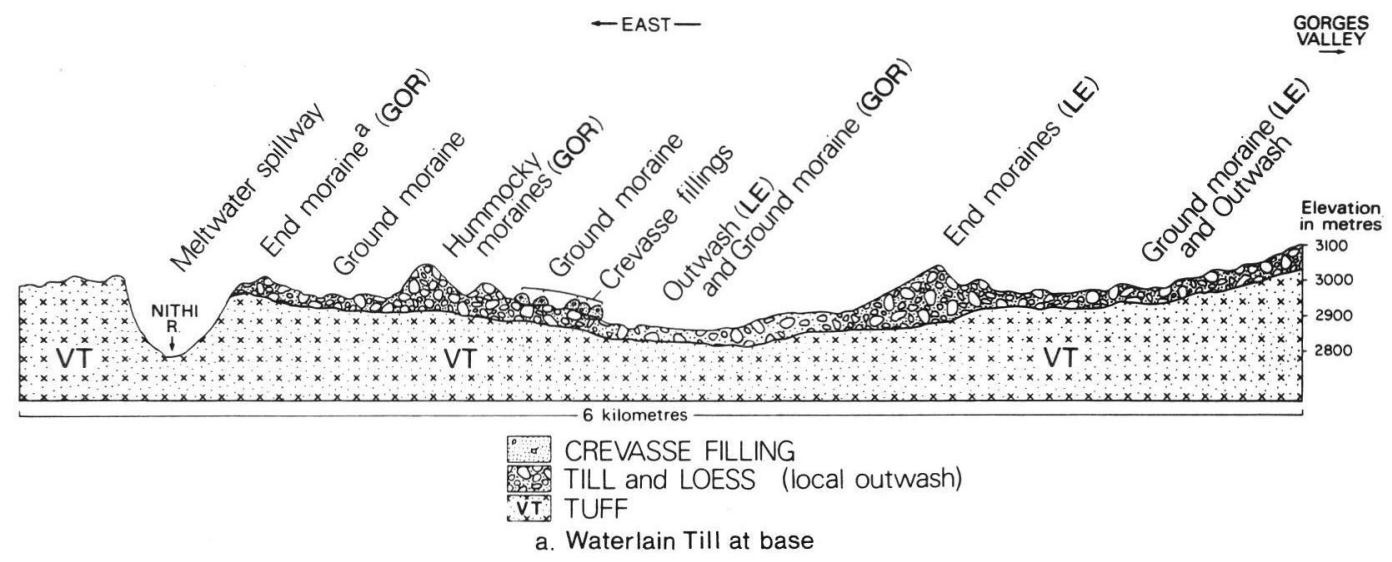

Fig.2: Landform profile showing morphosequences of deposits emplaced during Gorges and Lake Ellis glaciations. Glaciers moved from west to east; largest expanded mountain ice sheet occurred during the earlier Gorges Glaciation.

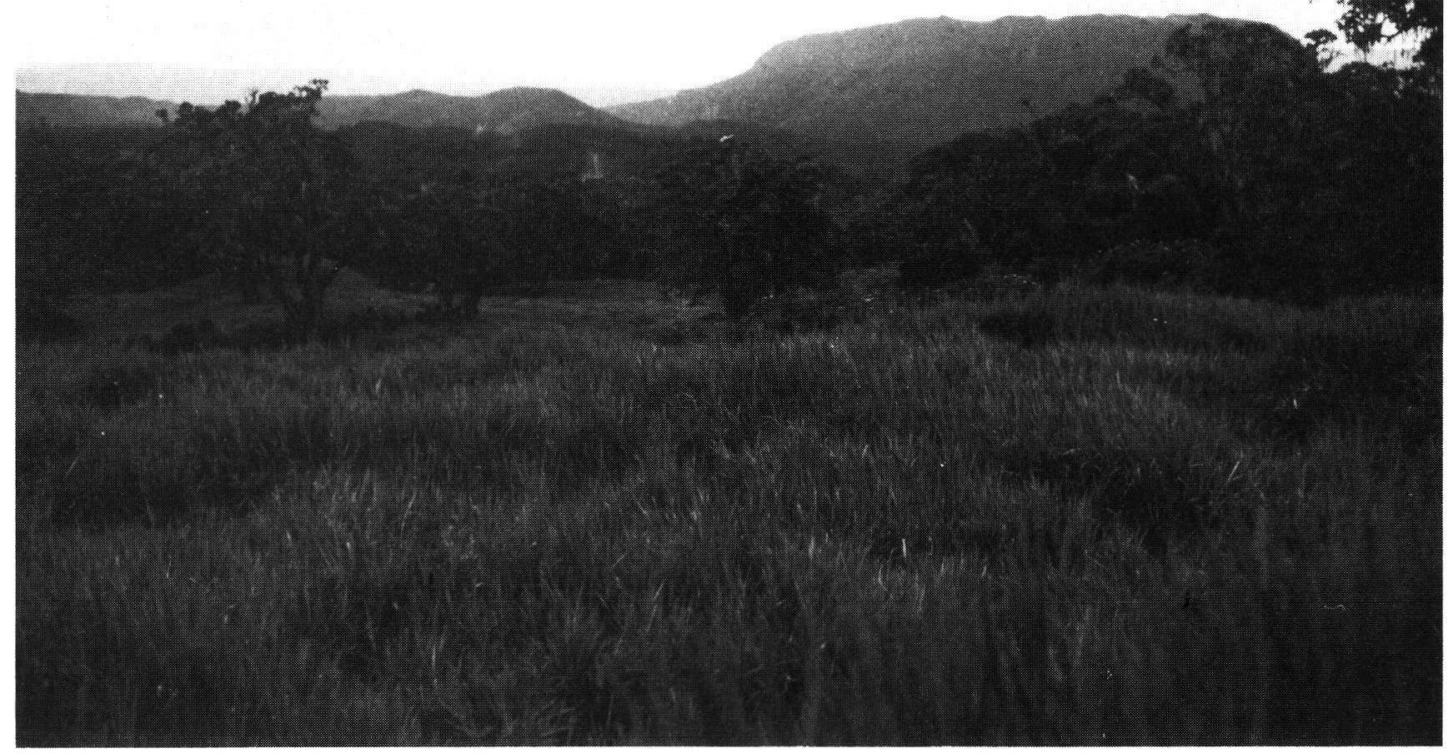

Fig. 3: Hummocky moraine deposited during the Gorges Glaciation $(1.67-1.87 \mathrm{my})$ in Gorges Valley. 


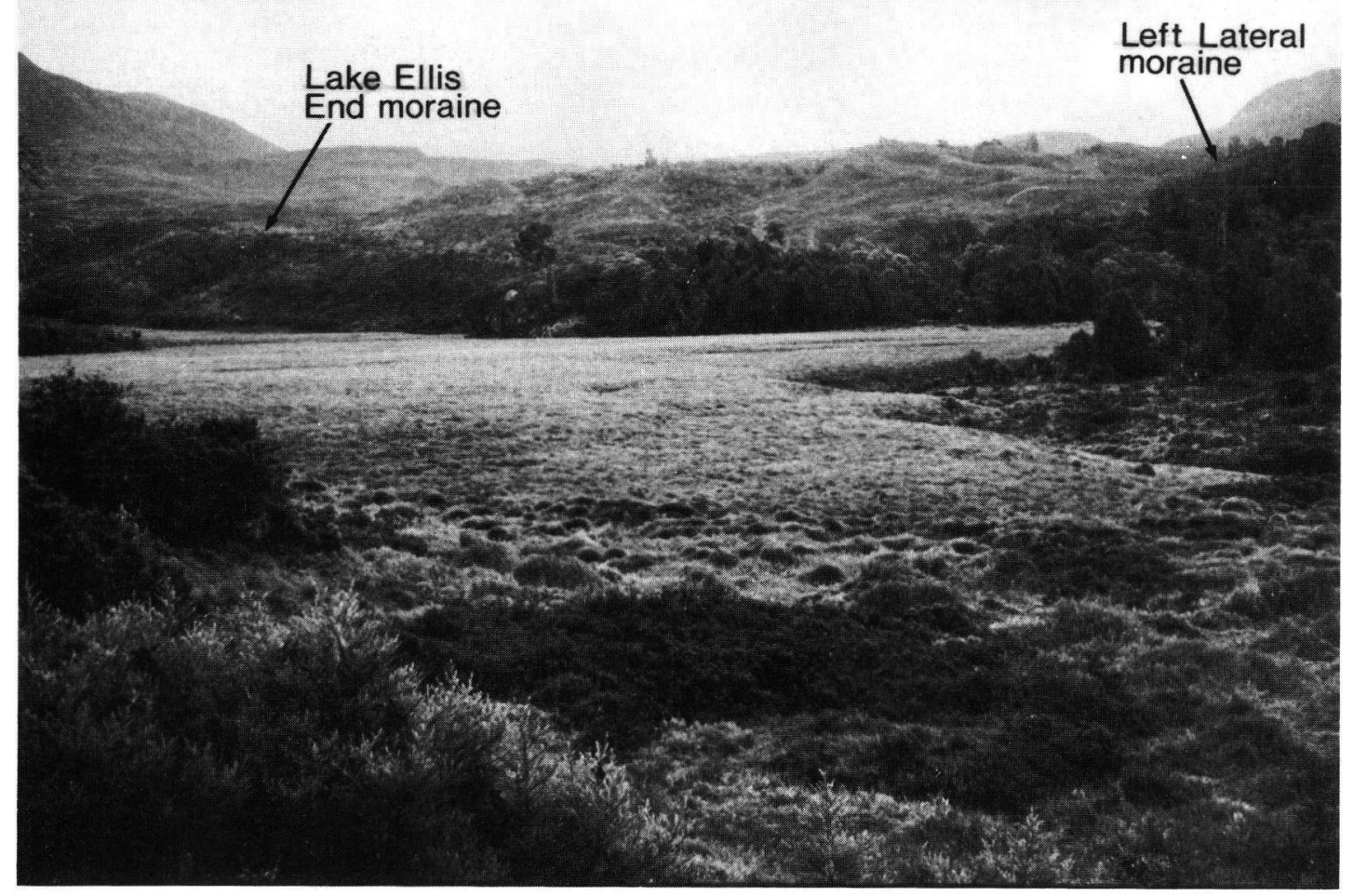

Fig. 4: Left lateral moraine (far right, background) emplaced during the Gorges Glaciation in Gorges Valley. Ridge of Lake Ellis drift (left of center), alluvium of postglacial period covering older outwash of Liki, Teleki and Lake Ellis ages, and proximal slope of the Gorges Moraine complex (foreground, left and right).

ured using guidelines established by MAHANEY et al. (1984). Paleomagnetic samples were collected following standard procedures as discussed by BARENDREGT (in MAHANEY et al. 1984) and by BARENDREGT \& MAHANEY, 1988).

\section{Landforms}

The major glacial landforms (Fig. 1) consisting of meltwater channels, complex end moraine underlain with waterlain till, end moraines, ground moraines, hummocky moraines, crevasse fillings, and outwash plains were not described by previous workers on Mount Kenya (NILSSON, 1935; BAKER, 1967; HASTENRATH, 1984). T. J. CHARSLEY (personal communication, 1984) first recognized extensive moraines as low as $2850 \mathrm{~m}$ on the eastern flank of the mountain, which were subsequently investigated by MAHANEY in $1984,1986,1987.1987,1990$. This led to the identification of morphostratigraphic units for two of the oldest glaciations - Gorges and Lake Ellis - on Mount Kenya. These units comprise a sequence of well-preserved deposits as shown in Figs. 2 through 5.

\subsection{End Moraines}

End moraine complexes consist of one or two ridge systems, usually abutting outwash fan deposits that are difficult to map from air photographs and satellite imagery. These moraine complexes are 100 to $200 \mathrm{~m}$ in width and 3 to $4 \mathrm{~km}$ in length, standing only a few meters higher than surrounding ground moraine. All the end moraines are covered with thin veneers of aeolian sediment. Individual deposits of Gorges Till commonly contain two lodgement tills separated by loess, overlying waterlain till. These tills record at least two and possibly three advances of Gorges ice during the Olduvai subchron between 1.7 and 1.9 my ago (MAHANEY, BARENDREGT \& VORTISCH, 1989). Because the lower beds in the outer Gorges moraine were deposited subaqueously along most of the length of the moraine, it is possible to make only limited inferences regarding ice dynamics and paleoclimate. 


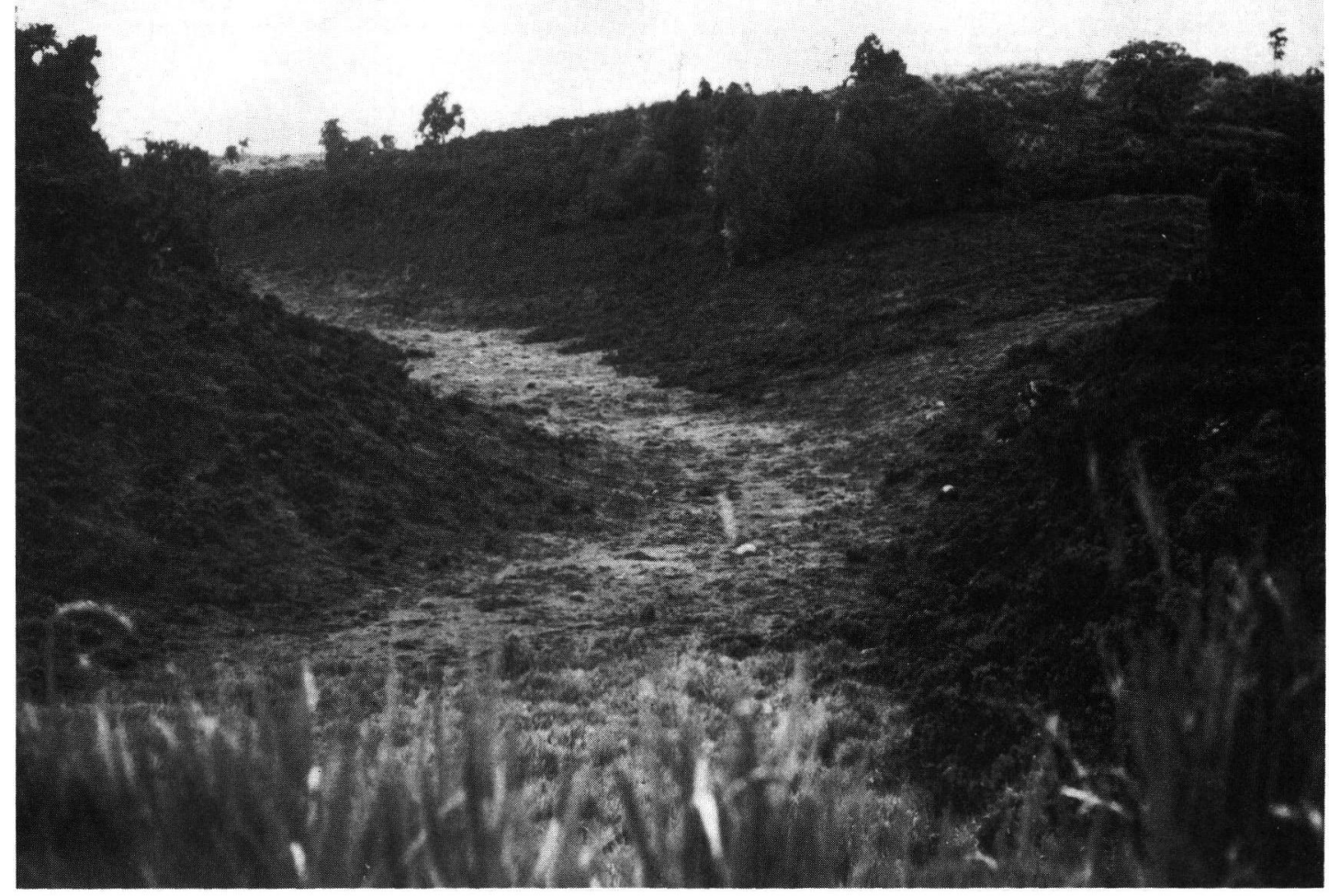

Fig. 5: Meltwater sluiceway in front of Gorges-age end moraine in Gorges Valley; left, distal moraine slope; right outcrops of tuff of the Mt. Kenya volcanic suite (early Quaternary).

\section{Sediments}

\subsection{Subaquatic Sediments}

Below the Gorges Glaciation lodgement tills, deposited by ice moving from west to east in lower Gorges Valley, waterlain till has been observed at four locations (Figs. 2 and 8). All sediments in this sequence exhibit horizontal bedding, lack appreciable deformation (minor deformation is visible), and have sharp and abrupt upper contacts with overlying lodgement till (details of the stratigraphy in Fig. 8). These sediments were deposited as poorly sorted beds about $2-4 \mathrm{~cm}$ in thickness that remain remarkably consistent with respect to particle size distributions from top to bottom. No subaquatic mass wasting or diamicton structures were observed, so it is possible to rule out episodic gravity flow deposition for these sediments (such as described by EvENSON et al. 1977).

Subaquatic deposition of these sediments may have occurred under thin mountain ice actively receding behind bedrock bars above the Nithi River outlet. Because the underlying weathered tuffs were preserved it is logical to assume that ice action was weak, and that sediment was being deposited subaqueously beneath floating ice, perhaps in shallow water dammed by ice in the meltwater channels leading into the Nithi River or in the main Nithi Valley itself. Because this sediment contains pebbles that could be considered dropstones, I measured the orientation of 50 clasts. The resulting fabric gave a bimodal distribution with stones oriented mainly toward $070^{\circ}$ and $105^{\circ}$ (nine samples gave spurious readings). The presence of a glacial fabric and minor deformation of beds in these sediments favor a glacial rather than a glaciolacustrine origin. However, additional data is needed to rule out the latter hypothesis. This type of sediment is only observed in the outer Gorges moraines and may be linked possibly to catastrophic ice surges followed by rapid melting or to sudden paleoclimatic warming followed by rapid deposition of till. 


\subsection{Ground Moraines}

Behind prominent end moraine complexes and beneath outwash and aeolian cover sediments, are numerous areas of ground moraine. In general, they are nearly flat topped and irregularly distributed in the landscape. Some are overlain with crevasse fillings that have been described as man-made mounds (see MAHANEY et al. 1986, for discussion). A number of exposures displayed irregular sequences of lodgement till with thin, sandy diamictons. Some may consist of crevasse fills or subglacial cavity collapse features, but most were probably formed prior to deposition of the hummocky-end moraine complexes. Deposition occurred on level or slightly sloping topography, presumably under thick ice with relatively high subglacial water pressures.

\subsection{Hummocky Moraine}

Broad hummocky moraine occurs less than $1.0 \mathrm{~km}$ behind the outer Gorges end moraine complex (Fig. 2). Several asymmetrically shaped hills separate depressions filled with assorted till, fine laminated stratified drift, and ponded sediments. The hummocky end moraines (Fig. 1) lie on the margin of a bedrock bar which was eroded by meltwaters issuing from both Gorges and Lake Ellis ice. This geomorphic setting may have resulted from thick and active ice during the third Gorges advance, which led to eventual thinning followed by stagnation and sedimentation of a range of clast sizes (e.g. from boulders to clay). These later advances emplaced deposits that are clearly different from the waterlain till in the outer end moraine complex, and possibly indicative of debris-covered ice (LAWSON 1981). Because the hummocky moraine belt is composed of thick drift $(\sim 30 \mathrm{~m})$, deposition probably occurred under active and thick ice conditions, followed by rapid stagnation and ice thinning that led to emplacement of numerous crevasse fillings.

\subsection{Lateral Moraines}

Lateral moraine complexes, easily identifiable on air photographs and LANDSAT imagery, define the outer margin of Gorges ice when the expanded mountain ice sheet occupied almost all of Gorges Valley and one unnamed tributary drainage to the north (Fig. 1). These moraines have steeper slopes and sharper crests compared with the end moraine complexes; they are $5-7 \mathrm{~km}$ in length, 50 to $150 \mathrm{~m}$ wide and up to $25 \mathrm{~m}$ high. Commonly they have single crests and together they account for a greater amount of sediment accumulation when compared with the end and ground moraine complexes.

\subsection{Crevasse Fillings}

Behind and around the hummocky belt an irregular distribution of conical mounds consisting of till and stratified sediments were interpreted to be crevasse fillings. Originally interpreted as man-made mounds (ZEUNER 1948) these deposits appear related to thinning and eventual breakup of the expanded mountain ice sheet following the third advance of ice during the Gorges Glaciation.

\subsection{Outwash}

Between the hummocky moraine belt of the Gorges Glaciation and the end moraines of Lake Ellis age (Fig. 2) a system of outwash deposits, built by streams flowing from active ice to the west, forms prominent terraces and fans in the landscape. While some of this outwash could have been deposited following the Gorges Glaciation, the major proportion appears to belong to the younger Lake Ellis Glaciation. Unlike the older Gorges Glaciation which left much of the underlying weathered bedrock intact, younger outwash of Lake Ellis age is found commonly in thin bodies ( $2-4 \mathrm{~m}$ thick) over scoured and fresh bedrock surfaces.

\subsection{Aeolian Sediments}

Wind blown sediments cap much of the outwash and till deposits (ZEUNER 1949), and in some cases (mainly around the margin of glaciation) even separate buried till sheets (e.g. Section GOR68, Fig. 8). As in other drainage basins around Mount Kenya aeolian sediments are high in quartz and low in ferromagnetic minerals when compared with tills (MAHANEY 1982; VORTISCH, MAHANEY \& FECHER 1987). Many of these aeolian deposits are thin $(\sim 0.5 \mathrm{~m})$ and almost all are weathered forming $\mathrm{A}$ or $\mathrm{Ab}$ horizons in paleosol sequences. Many contain histic or mollic epipedons (SOIL SuRvey STAFF, 1975) of considerable thickness that were formed under Afroalpine biotic elements during deteriorating climate when major vegetation belts occurred further down the mountain, a distance of at least $600 \mathrm{~m}$ (MAHANeY, HARMSEN \& SPENCE 1991).

\section{Weathering}

Weathering features on surface stones are only of limited use in distinguishing between Gorges and Lake Ellis deposits. This is partly the result of the location of deposits under different vegetation belts - Gorges moraines are situated under Hagenia woodland at present, whereas Lake Ellis drifts are under ericaceous vegetation (Fig. 1). Also several weeks of 


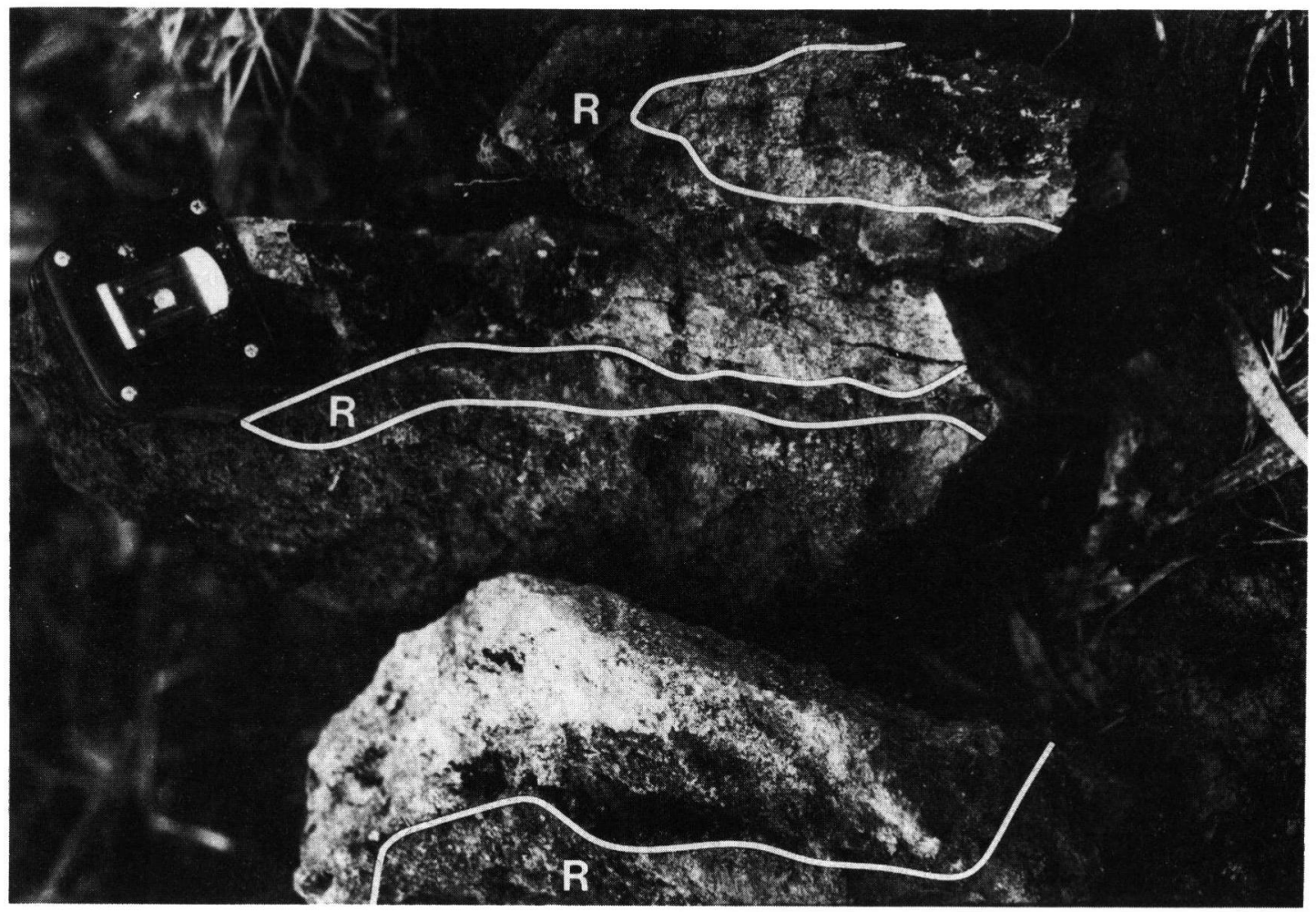

Fig. 6: Weathering rinds from outer Gorges end moraine, Nithi River Basin, Mount Kenya; R - rind (rock surface weathered to clay and $\mathrm{Fe}$ oxides).

observations in 1983/84, 1986 and 1987 showed that advection currents tend to force air masses upward to $\sim 3000 \mathrm{~m}$ bringing rain to approximately the same elevation. Above $\sim 3000 \mathrm{~m}$ climate is noticeably drier - the boundary coincides with Gorges and Lake Ellis deposits. Hence, stones on Gorges deposits are not only in a wetter microclimate, they are also older and have been exposed to subaerial weathering for a longer period of time. The result is that clasts on Gorges deposits (Fig. 6) have weathered to produce thick (20 to $30 \mathrm{~mm}$ ) clay and oxide-rich rinds. Stones on Lake Ellis drifts are somewhat fresher, although they can be split easily with a hammer.

\section{Stratigraphy}

The Gorges and Lake Ellis glaciations on Mount Kenya occurred prior to the Matuyama / Brunhes boundary $(>.73-.79 \mathrm{my}$ ) (Fig. 7 ), and spread to $2850 \mathrm{~m}$ on the eastern side of the mountain. Deposits emplaced during the earliest phase of the Gorges Glaciation (Fig. 8A) generally have normal magnetism $\mathrm{w}$ it $\mathrm{h}$ $\mathrm{r}$ e versed over prin t suggesting the tills were emplaced during the Olduvai subchron (see MAHANEY, BARENDREGT \& VORTISCH 1989, for discussion). Tills emplaced during the later phase of the Gorges Glaciation (Fig. 8B) have strongly reversed

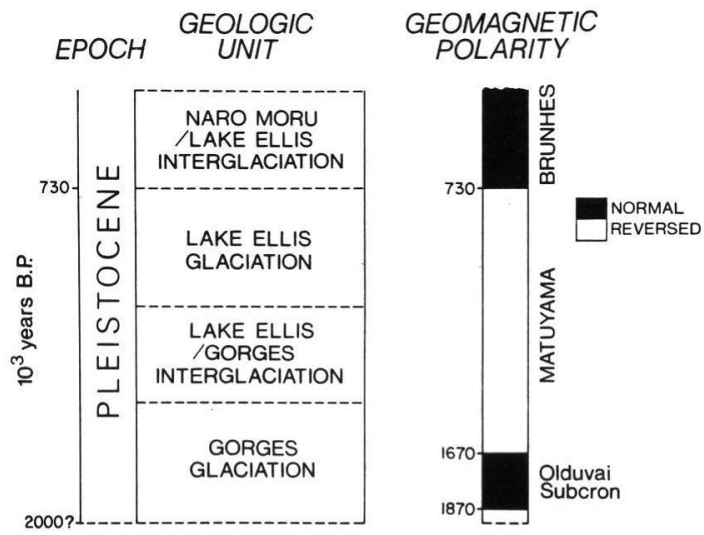

Fig. 7: Early to Middle Pleistocene stratigraphy of Mount Kenya, East Africa. 
remanent magnetism, which would indicate an age possibly in the middle of the Matuyama Chron. Younger drifts and outwash of Lake Ellis age (Fig. 8C) give strongly reversed remanent magnetism suggesting possibly an upper Matuyama age, presumably closer to the Matuyama/Brunhes boundary (Fig. 7). The Jaramillo subchron, although of limited duration, has never been identified in any of the paleomagnetic samples collected on Mount Kenya (R. W. BAREND. REGT, personal communication, 1987).

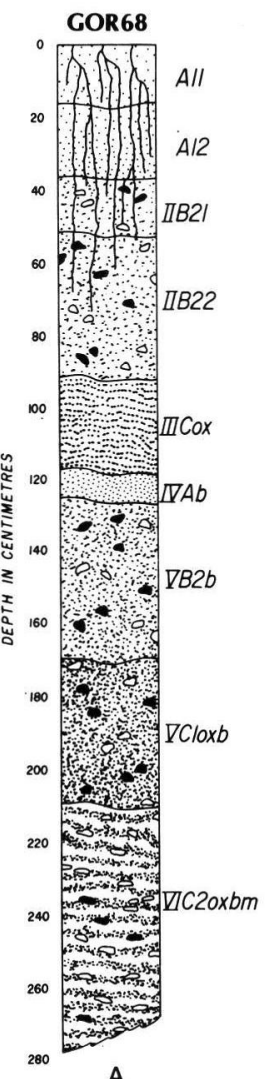

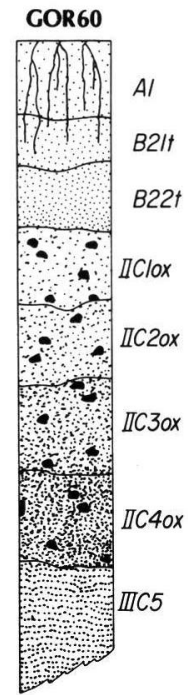

B.

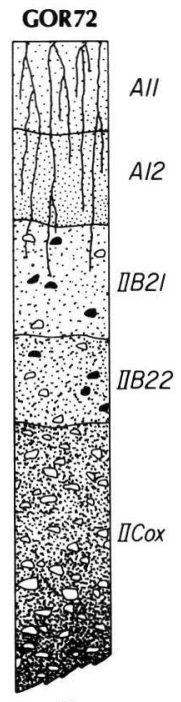

C.

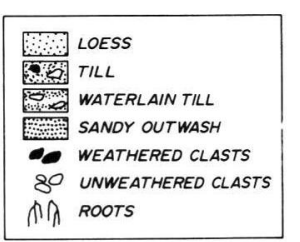

Fig. 8: Stratigraphy of tills, outwash, and loesses in sections (A) GOR 68 (outer Gorges moraine);

(B) GOR 60 (hummocky moraine of Gorges age); (C) and GOR 72 Lake Ellis age moraine.

Clast composition in both the Gorges and Lake Ellis deposits consists entirely of basalt with minor amounts of kenyte (glassy phonolite) appearing in the younger suite of samples. This suggests that during the Gorges Glaciation ice was eroding only roof rocks of basalt which still covered the volcanic plug of the mountain. During the ensuing Lake Ellis Glaciation glaciers were still excavating mainly basalts, but to a depth where they could also reach some exposed kenyte (commonly outcrops today at $\sim 4600 \mathrm{~m}$ ). The data presented by MAHANEY, BARENDREGT \& VORTISCH (1989) indicate that it took nearly 1.0 million years to remove most of the roof rock complex; subsequent removal of plug rock and formation of existing cirques in the Central Peaks area took about three quarters of a million years (for details on the erosion history see MAHANEY, HARMSEN \& SPENCE 1991).

\section{Conclusions}

This investigation of previously undescribed glacial landforms has led to a sequential arrangement of end moraines (with or without waterlain till), ground moraine, hummocky-end moraines (with crevasse fillings in the older group) and outwash that form distinctive morphosequences related to the earliest cycles of glaciation on Mount Kenya. Each morphosequence can be interpreted with respect to glacier dynamics and paleoclimate that provide important information about paleoenvironmental reconstruction in the tropical Afroalpine. The landform morphosequence is considered to represent the following glacial sequence: (a) thin ice flow depositing waterlain till in the outer Gorges end moraine complex; (b) somewhat more aggressive ice conditions leading to deposition of two tills separated by aeolian sediments; (c) deposition of hummocky-end moraines during an interval when ice appears to have been capable of moving considerable debris followed by stagnation and development of numerous crevasse fillings; and (d) development of an end moraine sequence in Lake Ellis time accompanied by emplacement of significant ground moraine and outwash bodies. The Lake Ellis Glaciation appears to have resulted from the simple forcing of a deterioriating paleoclimate, whereas the earlier Gorges Glaciation left a multitude of different landforms with important paleoenvironmental ramifications.

\section{Acknowledgments}

This research was partially supported by grant A 9021 of the Natural Sciences and Engineering Research Council of Canada. Steve Hicock and AleKsis DREIMANIS (University of Western Ontario) critically reviewed the manuscript. The abstract was translated into German by WOLFGANG ANDRES (Philipps Universität, Marburg, F.R.G.). Samples were analyzed in the Geomorphology and Pedology Laboratory in Atkinson College at York University with assistance of DAVID HINBEST. Field work was carried out with the permission of the Office of the President, Republic of Kenya. JANET Allin drafted the illustrations. 


\section{References}

BAKeR, B. H. (1967): Geology of the Mount Kenya Area. - Rept. No. 79: 78 p.; (geological Survey of Kenya).

BARENDREGT, R. W. (1984): Using paleomagnetic remanence and magnetic susceptibility data for the differentiation, relative correlation and absolute dating of Quaternary sediments. - In: W. C. MAHANEY (Editor), Quaternary Dating Methods: 101-122; Amsterdam (Elsevier).

- \& MAhaney, W. C. (1988): Paleomagnetism of selected Quaternary sediments on Mount Kenya, East Africa: a reconnaissance study. - J. African Earth Sciences, 7 (1): 219-225; Oxford, Frankfurt/M.

BirkelAND, P. W. (1984): Soils and Geomorphology. 372 p.; Oxford, N. Y. (Oxford Press).

Evenson, E. B., Dreimanis, A. \& Ǹewsome, H. (1977): The subaquatic flow tills: a new interpretation for the genesis of some laminated till deposits. - Boreas, 6: 115-134; Oslo.

EVERDEN, J. F. \& Curtis, G. H. (1965): The potassiumargon dating of late Cenozoic rocks in East Africa and Italy. - Current Anthropology, 6 (4): 343-385.

Gregory, J. W. (1894): The Glacial Geology of Mount Kenya. - Quart. Jour. of the Geological Society, 50: p. $515-530$.

- (1900): The geology of Mount Kenya. Quart. - Journ. Geol. Soc., 56: 205-222.

HastenRath, S. (1984): The Glaciers of Equatorial Africa. - 353 p.; Dordrecht (Reidel).

LAwson, D. E. (1981): Sedimentological characteristics and classification of depositional processes and deposits in the glacial environment. - U.S. Army Corps. of Engineers, CRREL Report: 81-27; Hannover, N.H.

MAHANEY, W. C. (1979): Reconnaissance Quaternary stratigraphy of Mount Kenya, East Africa. - In: E. M. vaN ZINDEREN BAKKER \& J. A. COETZEe (Editors), Palaeoecology of Africa, 10: 163-170; Rotterdam, Balkema.

- (1990): Ice on the Equator, Sister Bay, Wisc., Wm Caxton Ltd., 386 p.
Mahaney, W., Barendregt, R. W., Churcher, C. S. \& SPENCE, J. (1985): Gorges Valley rock shelters, Mount Kenya Afroalpine area, East Africa. - Nyame Akuna, 26: $21-25$.

-, - \& VORTISCH, W. B. (1989): Quaternary glaciations and paleoclimate of Mount Kenya, East Africa. In: Oerlemans, J.: Glacier Fluctuations and Climatic Change: 13-36; Dordrecht (Kluwer).

-, Halvorson, D., Piegat, J. \& Sanmugadas, K. (1984): Evaluation of dating methods used to assign ages to Quaternary deposits in the Wind River and Teton Ranges, western Wyoming. - In: W. C. MaHANEY (Editor) Quaternary Dating Methods: 355-374; Amsterdam (Elsevier).

—, Harmsen, R. \& SPence, J. R. (1991): Glacial-interglacial cycles and development of the Afroalpine ecosystem on East African mountains. - J. African Earth Sciences, 12: 505-512.

NiLsson, E. (1931): Quaternary glaciation and pluvial lakes in Bristish East Africa and Abyssinia. - Geog. Annaler, 13: 241-348.

- (1935): Traces of ancient changes of climate in East Africa. - Geog. Annaler, 12: 1-21.

Soll SuRveY Staff (1951): Soil Survey Manual. Washington, D.C. (U.S. Government Printing Office).

- (1975): Soil Taxonomy. - Agriculture Handbook: 436 p.; Washington (U.S.D.A.).

Vortisch, W. B., Mahaney, W. C. \& Fecher, K. (1987): Lithology and weathering in a paleosol sequence on Mount Kenya, East Africa. - Geologica et Paleontologica, 21: 245-255; Marburg/Lahn.

ZeUNER, F. E. (1948): Climate and early man in Kenya. - Man, 48: 13-16.

- (1949): Frost soils on Mount Kenya and the relation of frost soils to aeolian deposits. - J. Soil Science, 1: 20-30; Oxford.

Manuscript accepted 20. March 1990, supplements September 1990. 